Радзієвська Ірина Володимирівна кандидат педагогічних наук, Заслужений працівник охорони здоров'я України, Проректор, Черкаська медична академія, вул. Хрещатик, 215, м. Черкаси, 18002, тел.: (93) 658-90-95, https://orcid.org/0000-0002-5216-1928

\title{
МЕТОДОЛОГІЧНІ ПІДХОДИ ДОСЛІДЖЕННЯ ТЕОРЕТИЧНИХ І ПРАКТИЧНИХ ЗАСАД РОЗВИТКУ МЕДИЧНОЇ ТА ФАРМАЦЕВТИЧНОЇ ОСВІТИ МОЛОДШИХ СПЕЦАЛІСТІВ
}

Анотація. Дослідження теоретичних і практичних засад розвитку медичної та фармацевтичної освіти молодших спеціалістів в Україні (XX - початок XXI століття) грунтується на розробленні періодизації розвитку медичної та фармацевтичної освіти молодших спеціалістів в Україні у XX - на початку XXI ст. та визначення особливостей професійної освіти фахівців галузі охорони здоров’я в Україні у кожному історичному періоді. На необхідності підвищення якості освіти медичних спеціалістів наголошується в Законі України «Про вищу освіту», «Національній стратегії розвитку освіти в Україні на 2012-2021 роки», Міжгалузевій комплексній програмі «Здоров'я нації», «Концепції розвитку громадського здоров'я». Особливо це стосується підготовки медичних i фармацевтичних кадрів, що пов'язано 3 необхідністю підвищення якості освіти відповідно до вимог сучасної практичної медицини. Концепція розвитку охорони здоров'я України передбачає реалізацію інноваційної та кадрової політики в системі охорони здоров'я: «удосконалення системи підготовки медичних і фармацевтичних спеціалістів, розробка та впровадження освітніх стандартів у навчальний процес, розширення функцій медичних працівників та фармацевтичних спеціалістів відповідно до світового досвіду». Дослідження засад розвитку освіти потребує історико-педагогічного підходу який грунтується на теоретичних ідеях і досвіді історично-педагогічних досліджень у галузі історії освіти. У контексті проведеного дослідження, ми розробили власну періодизацію теоретичних i практичних засад розвитку медичної та фармацевтичної освіти молодших спеціалістів, яку виокремили та обгрунтували в поєднанні чотирьох періодів. В основу поділу покладені зміни, що відбувалися в країні в досліджуваний період: історичні, соціально-політичні, соціальноекономічні, євроінтеграційні, реформи в освіті, що вплинули на розвиток та удосконалення теоретичних та практичних засад підготовки фахівців.

Ключові слова: методологічні підходи, засади розвитку освіти, молодші медичні та фармацевтичні спеціалісти, фахова передвища освіта

Radziievska Iryna Volodymyrivna Candidate of Pedagogical Sciences, Honored Health Worker of Ukraine, Vice-Rector, Cherkasy Medical Academy, Khreshchatyk St., 215, Cherkasy, 18002, tel .: (93) 658-90-95, https://orcid.org/0000-0002-5216-1928 
Журнал«Герспективитаінновації наукиљ

(Серія«Гедагогіка», Серія«ГТихологія», Серія«Медицина»

№2(7) 2022

\section{METHODOLOGICAL RESEARCH APPROACHES TO THEORETICAL AND PRACTICAL FOUNDATIONS OF DEVELOPMENT OF MEDICAL AND PHARMACEUTICAL EDUCATION OF JUNIOR SPECIALISTS}

Abstract. The study of theoretical and practical foundations of the development of medical and pharmaceutical education of junior specialists in Ukraine (XX - early XXI century) is based on the periodization development of medical and pharmaceutical education of junior specialists in Ukraine in the XX-beginning of the XXI century and the definition of the features of professionaleducation of healthcare specialists in Ukraine in each historical period. The necessity to improve the quality of education of medical specialists is emphasized in the law of Ukraine "On Higher Education", "National Strategy for the Education Development in Ukraine for 20122021", the Intersectoral Comprehensive Program "Health of the Nation", "Concepts for the Development of Public Health". It is especially true of the training of medical and pharmaceutical personnel, which is associated with the need to improve the quality of education in accordance with the requirements of modern practical medicine. The concept of development of Public Health Protection of Ukraine provides for the implementation of innovative and personnel policy in the healthcare system: "improving the training system of medical and pharmaceutical specialists, developing and implementing educational standards in the educational process, broadening the functions of medical and pharmaceutical specialists in accordance with the world experience". The study of the foundations of the education development requires a historical and pedagogical approach based on theoretical ideas and experience of historical and pedagogical research in the field of the education history. In the context of the research, we have developed our own periodization of theoretical and practical foundations for the development of medical and pharmaceutical education of junior specialists, identified and justified in a combination of four periods. The division is based on changes taking place in the country during the study period: historical, socio-political, socio-economic, European integration, reforms in education affecting development and improvement of theoretical and practical foundations for specialists training.

Keywords: methodological approaches, fundamentals of education development, junior medical and pharmaceutical specialists, professional education

Постановка проблеми. Сучасна історія педагогіки спирається на різноманітні методологічні підходи до аналізу системи освіти. Вивчення засад розвитку вітчизняної медичної та фармацевтичної освіти в Україні уможливило виявлення ряду суперечностей між: потребою в здійсненні теоретичної та практичної підготовки фахівців 3 урахуванням прогресивного світового i європейського досвіду та відсутністю відповідного змістового забезпечення освітнього процесу; потребою в організації компетентнісно й особистісноорієнтованої підготовки майбутніх молодших спеціалістів та існуючими традиційними підходами до методів освіти, застосуванням застарілих форм і 
методів навчання; потребами суспільства в отриманні якісних та доступних медичних (фармацевтичних) послуг та неготовністю закладів освіти до розв'язання відповідних завдань 3 підготовки фахівців достатнього кваліфікаційного рівня.

Аналіз останніх досліджень і публікацій. Опрацювання джерельної бази здійснювалось на межі хронологічного та системного підходів та враховувало наближеність до теми пошуку стосовно огляду та опрацювання широкого кола джерел 3 історії розвитку освіти - історико-педагогічну літературу, щодо теоретичної та практичної підготовки молодших фахівців галузі охорони здоров'я, статті в педагогічних періодичних виданнях, тези конференцій. Ученими-педагогами висвітлювались різноманітні методологічні підходи та принципи науково-педагогічного дослідження: стадіально-формаційний підхід (Є. Хриков, 2018), системний підхід (О. Кустовська, 2005), цивілізаційний та антропологічний підходи (Г. Корнетов, 1994), акмеологічний підхід (О. Дубасенюк, 2017; І. Ніколаєску, 2016), культурологічний підхід (С. Машкіна, Т. Усатенко, Л. Хомич, Т. Шахрай, 2016), синергетичний підхід (С. Вітвицька, 2006), герменевтичний підхід (А. Линенко, 2016). Це уможливило розвинути і поглибити дослідження із заявленої тематики.

Мета статті - узагальнення системи взаємопов'язаних підходів та принципів дослідження теоретичних і практичних засад розвитку медичної та фармацевтичної освіти молодших спеціалістів в Україні з урахуванням нових освітніх тенденцій.

Виклад основного матеріалу. В рамках проведення дослідження теоретичних і практичних засад розвитку медичної та фармацевтичної освіти молодших спеціалістів нами були застосовані різноманітні методологічні niдxодu щодо аналізу суспільних подій (явищ, процесів) та педагогічних ідей i педагогічної думки у визначений історичний період.

Стадіально-формаџійний підхід сприяв усвідомленню того, що поступовість руху історичних подій, від нижчої стадії до вищої, дозволяє по різному осмислити вирішальну роль духовних $i$ матеріальних чинники суспільного розвитку громади. Хоча, з точки зору даного підходу вирішальну роль у розвитку суспільства відіграють матеріальні (економічні) чинники, у сучасному соціально-економічному устрої поступово відбувається заміщення праці знаннями, тобто «онтологізація інформації й перетворення їі на основний виробничий ресурс» [1, с. 134].

3 початку XX століття одним 3 головних пріоритетів створення мережі закладів медичної та фармацевтичної освіти було забезпечення галузі охорони здоров'я достатньою кількістю підготовлених працівників, що можуть виконувати свої виробничі функції. 3 часом відбулися якісні зміни. Запити держави до системи медичної (фармацевтичної) освіти розширили коло пріоритетів - тепер вирішальним питанням є не тільки забезпечення закладів охорони здоров'я i аптечних установ людськими ресурсами, а облік оптимального співвідношення різних категорій медичних (фармацевтичних) 
працівників, що забезпечать надання ефективних послуг достатнього рівня якості. Такий підхід потребує розроблення нового покоління освітніх програм, які забезпечать ревалентність навчально-методичного забезпечення освітнього процесу та підвищення рівня професійних знань здобувачів освіти.

Одним із напрямків методології наукового пізнання є системний підхід, за допомогою якого ми вивчали професійну освіту молодших спеціалістів медичного та фармацевтичного спрямування, як складну систему, що складається 3 певних складових: додипломної освіти, післядипломної освіти та активного неперервного навчання протягом усього життя. Застосування системного підходу дозволило дослідити систему медичної та фармацевтичної освіти як цілісний об'єкт (структурно-логічну конструкцію), що об’єднує певну кількість взаємопов'язаних складових (елементів). Оскільки дослідження системи здійснюється у поєднанні 3 дослідженням умов іï функціонування у зовнішньому середовищі [2, с. 34], нами здійснено системно-структурний аналіз теоретичної і практичної підготовки молодших спеціалістів галузі охорони здоров'я в рамках досліджуваних чотирьох історичних етапів у XX - початку XXI ст. Системний підхід сприяв уточненню організаційної структури освітніх закладів та виявленню чинників, що впливали на їх розвиток та функціонування. Реформування та розвиток системи медичної (фармацевтичної) освіти розглядались як способи розв'язання проблеми якості освіти, як сукупність необхідних знань та умінь, набутих здобувачами освіти, матеріально-технічного забезпечення закладів освіти, засобів навчання, організації діяльності педагогічних колективів, що спрямовані на розв'язання поставленої проблеми.

Для дослідження специфіки організації освітнього процесу в медичних та фармацевтичних закладах освіти - форм, методів i засобів навчання, використовувався діяльнісний підхід. Дослідження проводилось під час теоретичних та семінарських занять, на заняттях навчальної практики у навчально-тренінгових кабінетах та у Центрі стимуляційного навчання Черкаської медичної академії, де разом 3 навчанням магістрів і бакалаврів здійснюється і підготовка молодших спеціалістів. Вектор дослідження був спрямований на усвідомлення здобувачами освіти важливості продовження навчання на вищих освітніх рівнях, підвищенні власного професійного рівня, розвиток важливих особистісних якостей для майбутньої роботи з пацієнтами та членами їх сімей.

На засадах стадіально-формаційного, системного та діяльнісного підходів обгрунтовано важливість застосування новітніх освітніх технологій при проведенні теоретичної та практичної підготовки молодших спеціалістів медичного та фармацевтичного спрямувань.

Цивілізаційний підхід, розроблений Г. Корнетовим (1994 р.), описує цілісність всесвітнього історико-педагогічного процесу is суворо ієрархізованими й взаємопов'язаними рівнями всезагального, загального, особливого й одиничного [3]. 3 точки зору цивілізаційного підходу вирішальну 
роль у розвитку суспільства відіграють не тільки економічні чинники, а головним чином, розвиток науки, культури, особистості, тобто розвиток духовної сфери і основою суспільного прогресу виступають загально-людські цінності. Цивілізаційний підхід сприяв вивченню прогресивних систем професійної освіти майбутніх медичних та фармацевтичних спеціалістів, орієнтованих на їх інтелектуальний розвиток, креативність, розвиток майбутнього медика i фармацевта, як всебічно розвиненої особистості 3 високими моральними цінностями.

Державною програмою розвитку освіти в Україні на період до 2021 року визначені основні пріоритетні напрями: європейський рівень якості, доступність, створення системи неперервної освіти, соціальний захист, забезпечення потреб суспільства i держави у висококваліфікованих i конкурентоспроможних фахівцях, розвиток суспільства на основі нових знань. За думкою О. Дубасенюк, універсальним методологічним орієнтиром, що забезпечує цілеспрямованість та результативність освітньої діяльності, виступає акмеологічний підхід до вивчення закономірностей досягнення вершин професіоналізму та творчості, який є одним із прогресивних та перспективних для сучасної системи освіти [4, с. 25-30]. Акмеологія (від грецького акме вершина, найвищий ступінь розквіту) - наука про закономірності і механізми розвитку людини на етапі іï дорослості, особливо при досягненні нею найвищих вершин у життєдіяльності та самореалізації творчого потенціалу.

I. Ніколаєску вбачає сутність акмеологічних технологій у їх спрямованості на розвиток особистості та професійного мислення фахівця та розглядає акмеологічні технології як інтегровану систему, що вміщує п’ять технологій: проектування i реалізацію освітньої програми; управління організаційнопедагогічними процесами; виховання духовно-морального потенціалу людини; успішного навчання; акмеологічого супроводу педагогічного процесу [5, с. 12]. О. Дубасенюк зазначає, що акмеологічний підхід має вплив на особистіснопрофесійне становлення, саморозвиток фахівців у процесі їх професійної діяльності: підвищення рівня самосвідомості, самопізнання, свідоме володіння прийомами самоосвіти та самовиховання на основі продуктивної позитивної «Я»-концепції К. Роджерса, що характеризується рухом від «Я»-реального до «Я»-ідеального та усвідомленим керуванням розвитком «Я» на основі самоспостереження, рефлексії, саморегуляції [4, с. 25-30; 6, с.122].

Застосування акмеологічного підходу у процесі наукової розвідки дозволило: визначити стадії професійного саморозвитку здобувачів освіти на усіх етапах становлення їх як особистості від початкової стадії - вступу до підготовленості до майбутньої діяльності - випуску; окреслити психологічний портрет молодшого спеціаліста медичного та фармацевтичного напряму; знайти шляхи реалізації підвищення якості його професійної підготовки. У контексті акмеологічного підходу «системним i цілісним феноменом» [4, с. 25-30] постають особистісно орієнтований, гуманістично-орієнтований та соціальногуманістичний підходи. 
Журнал«Герспективитаінноваціїнаукиљ

(Серія«Гедагогіка», Серія«Гтихологія», Серія «Медицине»

№2(7) 2022

Особистісно орієнтований підхід застосовувався під час дослідження особливостей теоретичної та практичної підготовки здобувачів медичних та фармацевтичних освітніх закладів, як студентоцентрованого процесу, спрямованого на розвиток почуття власної гідності, самоповаги, наполегливості при досягненні поставленої мети, формування необхідних моральних якостей для майбутнього медика та фармацевта - уміння співпереживати, співчувати, бути доброзичливим, уміти працювати в команді.

Гуманістично-орієнтований та сочіально-гуманістичний підходи дозволили здійснити узагальнення видів діяльності закладів освіти щодо: запровадження організаційних форм навчання, обліку успішності та оцінювання знань та умінь студентів; встановлення критеріїв оцінювання результатів навчання та діяльності викладачів; використання викладачами інноваційних технологій навчання; інформатизації освітнього процесу; створення суб'єктсуб'єктної взаємодії між викладачем та студентом з метою розвитку здібностей та інтересу до обраної професії.

Система української медичної та фармацевтичної освіти 3 початку XX століття і дотепер постійно знаходиться в стані пошуку нових шляхів реформування згідно зі змінами, що відбуваються в історії нашої держави та суспільстві, вимогами Європейського Союзу щодо якості професійної підготовки шляхом упровадження нових моделей навчання. Сьогодення ставить перед освітою нові виклики та чекає у відповідь ефективних та рішучих дій. Одним з таких викликів медична (фармацевтична) освітянська спільнота вважає «професійне вигорання» фахівців, що $є$ наслідком внутрішньої відчуженості людини від набутих знань, виконуваної професії і соціуму. В результаті втрачається смислова цінність буття людини і відбувається формування «гуманітарної кризи».

Окреслюючи головні цілі, що стоять перед освітою, більшість дослідників вважають оптимальним рішенням зазначеної проблеми гуманітаризацію (гуманізацію), сприяння всебічному особистісному (культурному, творчому) розвитку здобувачів освіти. Для розв'язання цих питань, крім означених вище особистісно-орієнтованого, гуманістично-орієнтованого та соціальногуманістичного підходу, можна запропонувати також культурологічний підхід.

Проводячи наукові розвідки в педагогіці з кута культурологічного підходу, дослідники С. Машкіна, Т. Усатенко, Л. Хомич, Т. Шахрай зазначають, що «наше суспільство переживає складний процес історичного розвитку» [7, с. 6]. Серед засад, що впливають на систему освіти, названі: національно-культурне відродження України; становлення державності; глибока криза економічних, політичних i духовних сфер суспільного життя. Саме 3 відродженням культурно-творчої місії вищої школи, а також переходом до культуротворчої системи освіти взагалі, вважають автори, пов'язане удосконалення системи професійної освіти [7, с. 7].

Ще у 1988 році Единбурзька декларація Всесвітньої федерації медичної освіти серед дванадцяти принципів реформування медичної освіти означила, 
зокрема: мультипрофесійну освіту; побудову освіти в контексті національних пріоритетів; підготовку викладачів закладів медичної освіти як педагогів і освітян; відбір абітурієнтів за інтелектуальними і іншими професійними якостями. Цього можна досягти, якщо в закладах освіти поряд 3 професійною буде запроваджена загальнокультурна підготовка, що досягається єдністю змісту, форм, засобів і методів освіти які стимулюють духовний розвиток здобувачів.

Застосування культурологічного підходу в дослідженні теоретичних i практичних засад розвитку медичної та фармацевтичної освіти молодших спеціалістів, дозволило нам, 3 одного боку, дати оцінку особистісних властивостей викладачів медичних (фармацевтичних) закладів освіти (за системою С. Машкіної) - їх світоглядних позицій, системи цінностей, переконань, ціннісно-емоційного ставлення до себе, студентів, колег, науки, культурно-духовних надбань, предмету, який викладають, з іншого, здійснити аналіз проблеми розвитку вітчизняної медичної та фармацевтичної освіти 3 урахуванням національних пріоритетів i традицій, культурного розмаїття громад, що проживають в Україні, з означенням перспективних напрямків професійної освіти, які б сприяли розбудові національної культури.

Педагогічна концепція С. Гессена, розроблена ще на початку XX століття, в своїй основі містить ідею, що загальнолюдські цінності культури здійснюються лише у своїй індивідуальній та національній різноманітності, а нація, яка відривається від загальнолюдських цінностей, втрачає свою національну ідентичність [8, с. 82]. При цьому, сучасна система освіти, як зазначає С. Вітвицька, та досягнення сучасної науки, які протягом останніх десятиліть вступили в новий постнеокласичний етап свого розвитку, мають сприяти виконанню усіх, поставлених перед ними завдань [9, с. 10]. Синергетику вважають міждисциплінарною наукою, що займається вивченням процесів самоорганізації і виникнення, підтримки стійкості і розпаду структур (систем) різної природи. С. Вітвицька називає «основною прикметою сучасної педагогічної освіти найрозвиненіших країн світу - процес узгодження іiі трансформації із динамікою сучасного розвитку цивілізації» [9, с. 11]. Процес трансформації освітньої системи визначає іiї нову освітню тенденцію - гнучкість та здатність до самооновлення, сприяння переходу від класичної моделі освіти до неперервної. Синергетичний підхід в педагогіці використовують для аналізу національних освітніх систем, принципів їх самоорганізації, самоактуалізації, саморозвитку та самоуправління. У нашому дослідженні синергетичний підхід застосувався як метод дослідження системи медичної та фармацевтичної освіти молодших спеціалістів під час їх теоретичної та практичної підготовки, висвітлення процесу готовності випускників закладів освіти до професійної діяльності, із зосередженням уваги на самостійній (позааудиторній) роботі студентів, їх самоорганізації та самореалізації.

Формування цілісної, самодостатньої всебічнорозвиненої людини є одним із завдань освітньої галузі. Г. Корнетов, вивчаючи теорію історії педагогіки 
зазначав, що 3 кінця 80-х років XX століття учені-педагоги «намагаються наповнити теорію i практику освіти реальним антропологічним змістом. Пропагується гуманістична педагогіка, проектується особистісно орієнтовані технології й методики навчання, відроджується педагогічна антропологія та розробляється антропологічний підхід до вирішення проблем освіти» [10, с. 226]. Антропологічний підхід на сучасному етапі суспільного розвитку застосовується для пошуку нових шляхів і напрямків розвитку педагогічного знання, а також удосконалення освітньої діяльності.

В дослідженні антропологічний підхід використовувався для: 1) вивчення молодшого спеціаліста 3 медичною (фармацевтичною) освітою як особи, що взаємодіє 3 навколишнім середовищем, 3 власним внутрішнім світом, індивідуальністю, здатним до рефлексії, безперервного самовдосконалення i саморозвитку; 2) визначення місця в освітньому процесі особи викладача, його здатності до всебічного розуміння студента (бажань, потреб, мотивів поведінки), відношення до здобувача освіти - прийняття (або неприйняття) його прав на самоствердження, саморозвиток, свободу.

Зміна світогляду викладачів та студентів, нові ціннісні орієнтації, зміщення вектору освіти на гуманістичну парадигму сприяють удосконаленню освітнього процесу та успішній професійній орієнтації як викладачів так і студентів. При цьому прогресивну роль відіграє герменевтичний підхід [11, с. 57]. Енциклопедія освіти (2008р.) тлумачить поняття герменевтика як «мистецтво розуміння та осягнення смислу і значення знаків, теорія та загальні правила інтерпретації текстів». А. Линенко вважає, що герменевтичний підхід, як складова методологічного підходу, «отримав загальне визнання, тому що проблема розуміння пронизує всі сфери міжособистісних відносин: у науці, історії, економіці, політиці, культурі, освіті, вихованні тощо. Процес розуміння $\epsilon$ складною суперечливою міжсуб'єктною взаємодією в межах обміну ідеями, досвіду, принциповими позиціями і рішеннями, в прогнозуванні, оцінках реальних тенденцій у різних галузях знання. Процес взаємодії здійснюється не тільки в міжособистісній сфері, а й при віртуальному спілкуванні 3 різними текстами та їх авторами» [11, с. 55]. Герменевтичний підхід застосовувався під час опрацювання джерельної бази дослідження стосовно теоретичних i практичних засад розвитку медичної та фармацевтичної освіти молодших спеціалістів в Україні у XX - на початку XXI століть, сприяв іiі розумінню, узагальненню та практичному застосуванню на усіх етапах дослідження.

Застосування історіографічного підходу дозволило провести критичний аналіз історико-педагогічних джерел усіх історичних періодів розвитку медичної та фармацевтичної освіти молодших спеціалістів в Україні у XX початку XXI століть, вивчення теорії і практики медичної та фармацевтичної освіти у наукових працях учених; узагальнення наукових і емпіричних знань 3 означеної теми, залучення інформації для отримання об'єктивних висновків щодо означеної проблеми.

У європейському та національному світовому просторі спостерігається спрямованість освітнього процесу на розвиток здатностей у працівників 
вирішувати практичні задачі у різних сферах діяльності на базі набутих теоретичних знань. Пріоритетним напрямом державної освітньої політики щодо розвитку медичної та фармацевтичної освіти залишається компетентнісний підхід. Також, означена проблема удосконалення діючої системи освіти активно обговорюється i у науково-педагогічній науці. Компетентнісний підхід у освітньому процесі передбачає поєднання в системі освіти трьох параметрів соціального, психологічного і педагогічного, тобто: 1) єдності освітньої, розвивальної і виховної функції; 2) єдності цілей, змісту, методів організаційних форм і засобів навчання; 3) чіткого визначення основної мети і цілей освітнього процесу. Навчальна діяльність $є$ повноцінною за умови єдності i взаємопроникнення усіх трьох компонентів.

Компетентнісний підхід у дослідженні використовувався як метод дослідження особливостей підготовки молодших медичних та фармацевтичних спеціалістів у закладах освіти: від передачі знань і умінь предметного змісту до формування розвиненої особистості зі сформованими життєвими i професійними компетентностями, з високим рівнем мотивації до навчання. При цьому увага акцентувалась не на кількості інформації, що засвоює здобувач освіти під час теоретичного навчання, а на його здатності діяти у різних симульованих проблемних ситуаціях під час навчальної практики. При аналізі теоретичних і практичних засад медичної і фармацевтичної освіти молодших спеціалістів в Україні нами також була застосована методологія компаративних досліджень. Медична i фармацевтичні освіта в Україні розглядалась як складник загальної вітчизняної освітньої системи. Особливості та специфіка навчання в медичних та фармацевтичних закладах освіти характеризувались 3 точки зору загальних закономірностей і тенденцій розвитку освіти в державі у різні періоди історії XX - початку XXI століття.

Теоретична і практична підготовка медичних і фармацевтичних фахівців 3 початку XX століття здійснювалась відповідно до політичних та суспільноекономічних умов тих держав, яким належали частини українських земель. Частина західноукраїнських земель до 1917 року входила до складу АвстроУгорщини, інша частина (20-30 pp. ХХ ст.) до складу Польщі, Чехії, Румунії. Землі східної та центральної України належали Російській імперії, згодом Українській Народній Республіці. У 1937 році відбулось об'єднання західних, східних та центральних земель, Україна стала територіально єдиною і у статусі Української РСР ввійшла до складу СРСР, а з 1991 року, з проголошенням незалежності, стала суверенною Українською Державою. У роботі розглядаються теоретичні і практичні засади розвитку медичної та фармацевтичної освіти на всіх територіальновідокремлених українських землях з 1900 до 1930 року (початок ХХ століття), у період входження України в склад Радянського Союзу та проголошення незалежності України (1931-1970 рр.; 1971-2000рр.), завершується дослідження 2001-2020 роками (початок XXI століття).

Розгляд означених вище підходів був здійснений на основі загальнонаукових принципів, які $є$ тісно пов'язаними 3 дослідницькими методами та 
відігравали важливу методологічну роль у нашому дослідженні: принųип об'єктивності забезпечив: усунення суб'єктивізму, застосування чіткості в логічній побудові ходу дослідження, неупереджене наукове узагальнення підібраних літературних джерел та історичних подій досліджуваного періоду (XX - початку XXI століття); принциип науковості (описаний О. Сухомлинською) передбачив перевірку «висунутих ідей емпіричним шляхом», зокрема, теоретичних і практичних засад розвитку освіти в медичних i фармацевтичних освітніх закладах, узагальнення, доповнення, опрацювання, уточнення достовірності підібраної інформації [12]; принцип системності застосовано для дослідження окремих аспектів розвитку медичної та фармацевтичної освіти, що сприяло можливості теоретичного узагальнення їх як цілісної системи; принциип цілісності дозволив вивчити засади розвитку медичної та фармацевтичної освіти в процесі їх впливу на формування здобувача освіти як особистості, висвітлити роль навчальної та виховної роботи в системі освіти медичних (фармацевтичних) коледжем та училищ, показати різноманіття зовнішніх впливів, що позначаються на формуванні якостей особистості, на ході педагогічного процесу, оцінити методику керівництва цими впливами з боку суб'єктів освітнього процесу [13, с. 34-35]; принцип етичності сприяв усвідомленню відповідальності за адекватність і глибину аналізу, коректність критики, неприпустимість безпідставного схиляння перед авторитетами [14]; принцип гуманітарності передбачив спрямованість під час дослідження, насамперед, до особистості, їі здібностей та інтересів в ході зміни історичних етапів, аналізу суб’єкт-суб'єктної взаємодії викладачів та студентів, ї ціннісно-смислової рівності, діалогічності, саморозвитку через подолання труднощів [15, с.93]; принцип історичності дозволив виявити схожість i відмінність між досліджуваними явищами, виявити їх спорідненість, загальне й специфічне в їх розвитку [16, с. 57]; особливістю принципу історичності $\epsilon$ усвідомлення того, що, по-перше, процес розвитку медичної та фармацевтичної освіти триває, по-друге зміни в освіті відбуваються залежно від загальнокультурних, суспільно-історичних i соціально-економічних змін у країні; принции історико-часової корекції дозволив розглядати усі суспільні процеси та явища, що відбувались у досліджуваний період, послідовно та у відповідності до історичних умов, оцінити їх взаємозв'язок та взаємовплив у кожному виділеному історичному етапі та вплив на розвиток медичної та фармацевтичної освіти; принции динамічності виявив динаміку розвитку системи медичної (фармацевтичної) освіти, залежно потреб суспільства, культурного простору, світових освітніх тенденцій; принцип єдності логічного $i$ історичного використаний для дотримання логіки в проведенні дослідження та викладі матеріалу, відображення впливу історичних подій на освітній процес медичних та фармацевтичних закладів освіти, етапи розвитку освіти молодших спеціалістів, як відбувалися зміни в змісті, методах, засобах та організації процесу навчання фахівців галузі охорони здоров'я; принциип поєднання традицій та інновацій сприяв гармонізації сучасних тенденцій розвитку освіти 
3 накопиченим закладами освіти позитивним досвідом провадження освітньої діяльності. Історіографічне дослідження теоретичних i практичних засад розвитку медичної та фармацевтичної освіти молодших спеціалістів в Україні (XX - початок XXI століття) здійснювалось за такими критеріями: соціологічним; академічним; освітнім. Соціологічний критерій визначався за такими ознаками: вік вступників; гендерна рівність здобувачів освіти; соціальне походження. Ознаки академічного критерію: мережа закладів освіти, що здійснюють підготовку молодших медичних та фармацевтичних спеціалістів; кадрове забезпечення освітнього процесу (викладацький склад); матеріальнотехнічне забезпечення закладів освіти. Третій критерій, освітній, характеризувався ознаками - термін навчання; змістове (навчально-методичне) забезпечення; ступневість освіти; підвищення кваліфікації фахівців галузі охорони здоров'я.

Вивчення та узагальнення теоретичних i практичних засад розвитку медичної та фармацевтичної освіти молодших спеціалістів; обгрунтування етапів розвитку медичної та фармацевтичної освіти в Україні; аналіз змісту, методів, форм та організації підготовки медичних (фармацевтичних) спеціалістів; реформування та реорганізація освітніх закладів 3 курсів, шкіл у училища, технікуми, а потім в коледжі, інститути і академії; нові вимоги, що висувалися до організації освітнього процесу, здобувачів освіти, педагогічного та науково-педагогічного складу; зміни в системі середньої спеціальної освіти, iii перехід в систему вищої освіти, а згодом у фахову передвищу, дадуть змогу виявити закономірності професійної освіти та засади розвитку медичної та фармацевтичної освіти в Україні. Національні традиції та набутий грунтовний досвід підготовки фахівців галузі охорони здоров'я пришвидшать процеси іiі модернізації, гуманізації, гармонійного входження в європейський освітній простір, сприятимуть підвищенню конкурентоспроможності фахівців, виведуть освіту на якісно новий рівень, що цілком відповідає новій Стратегії розвитку медичної освіти в Україні.

Висновки. Теоретична та практична підготовка молодших спеціалістів в медичних (фармацевтичних) освітніх закладах має свою специфіку і відмінність оскільки кінцевою метою підготовки фахівця є збереження і зміцнення здоров'я населення. Підготовка та професійне удосконалення медичного та фармацевтичного персоналу повинно бути орієнтоване на особливості його діяльності в закладах охорони здоров'я та аптечній мережі, враховуючи фізіологічні, психологічні та вікові особливості здобувачів освіти. Вивчення взаємозв’язку між діяльністю та особистісними якостями спеціаліста дозволить визначити алгоритм його продуктивного професійного розвитку протягом всієї трудової діяльності. Методологічною основою дослідження теоретичних i практичних засад розвитку медичної та фармацевтичної освіти молодших спеціалістів в Україні, з урахуванням нових освітніх тенденцій, стала система взаємопов’язаних загальнонаукових та конкретно-наукових підходів, принципів та порівняльних критеріїв дослідження, що грунтується на вивченні вітчизняного досвіду підготовки фахівців галузі охорони здоров’я. 
Отже, методологія дослідження теоретичних і практичних засад розвитку медичної та фармацевтичної освіти молодших спеціалістів в Україні грунтується на вивченні вітчизняного досвіду підготовки фахівців галузі охорони здоров’я, розробленні періодизації засад розвитку їх професійної освіти та аналізі системи медичної та фармацевтичної освіти молодших спеціалістів у кожному історичному періоді, визначенні критеріїв порівняння теоретичних $\mathrm{i}$ практичних засад розвитку медичної та фармацевтичної освіти молодших спеціалістів в Україні (XX - початок XXI століття)

\section{Лimepamypa:}

1. Хриков Є.М. Методологія педагогічного дослідження: монографія: Монографія. Харків, 2018. С. 294. URL: http://dspace.luguniv.edu.ua/jspui/bitstream/123456789/4827/1.pdf.

2. Кустовська О. В. Методологія системного підходу та наукових досліджень: Курс лекцій. Тернопіль : Економічна думка, 2005. 124 с. URL: http://library.wunu.edu.ua/files/EVD/kl_mspnd.pdf.

3. Корнетов Г.Б. Цивилизационный подход как метод историко-педагогического исследования аксиологических проблем образования. Образование: идеалы и ценности (историко-теоретический аспект). Москва, 1995. С. 16-34.

4. Дубасенюк О.А., Антонова О.С. Методика викладання педагогіки: курс лекцій: вид.2, доповнене. Житомир: Вид-во ЖДУ ім. I. Франка, 2017. 327 с. URL: http://eprints.zu.edu.ua/29033/1/курс\%20лекцій.pdf

5. Ніколаєску I. О. Науково-методичний супровід професійно-педагогічної самореалізації викладача системи післядипломної освіти засобами інформаційнокомунікаційних технологій. Народна освіта, 2016. Вип. 3. С. 35-41. URL: http://nbuv.gov.ua/UJRN/NarOsv_2016_3_8.

6. Столяренко Л.Д. Педагогическая психология. Серия «Учебники и учебные пособия». 2-е изд., перераб, и доп. Ростов н/Д: «Феникс», 2003. 544 с.

7. Машкіна С.В., Усатенко Т.П., Хомич Л.О., Шахрай Т.О. Теоретичні засади культурологічного підходу у підготовці педагога до виховної діяльності. Монографія. ІПООД НАПН України, 2016. 168 c. URL: https://core.ac.uk/download/pdf/141487946.pdf.

8. Гессен С. И. Основы педагогики. Введение в прикладную философию. Отв. ред. и сост. П.В. Алексеев. Москва: «Школа-Пресс», 1995. 448 с. URL: https://dbs-lin.ruhr-unibochum.de/personalitaet/pdf/111.pdf.

9. Вітвицька С.С. Основи педагогіки вищої школи : підруч. за модул.-рейтинг. системою навчання для студентів магістратури. М-во освіти і науки України, Житомир. держ. ун-т імені Івана Франка. Київ: Центр навч. літ., 2006. 383 с. : рис, схеми.

10. Корнетов Г.Б. История педагогики : Введ. в курс «История образования и пед. Мысли» : Учеб. пособие для студентов вузов, обучающихся по специальностям (ОПД.Ф. 02. Педагогика). Москва : Изд-во УРАО, 2003. 292, [2] с. (Педагогическое знание / Ун-т Рос. акад. образования).

11. Линенко А. Ф. Професійна ідентичність в контексті професійної підготовки майбутнього вчителя: теоретичний аспект дослідження. Наука і освіта, 2016. № 1. С. 72-76. URL: http://nbuv.gov.ua/UJRN/NiO_2016_1_16.

12. Сухомлинська О.В. Методологія дослідження історико-педагогічних реалій другої половини $\mathrm{XX}$ століття. Шлях освіти, 2007. № 4. URL: https://lib.iitta.gov.ua/9006/1/Стаття\%200.В.\%20Сухомлинської1.pdf.

13. Курлянд 3.Н., Хмелюк Р.І., Семенова А.В. та ін. Педагогіка вищої школи: Навч . посіб. / За ред. З.Н. Курлянд. 3-те вид., перероб. і доп. Київ: Знання, 2007. 495 с. URL: https://library.udpu.edu.ua/library_files/416808.pdf. 
14. Хриков С.М. Методологічна функція законів та закономірностей педагогічної науки у історико-педагогічних дослідженнях. Збірник наукових праць. Педагогічні науки. Випуск 40. Херсон: ХДУ, 2005. 460 с. С. 37-42.

15. Фирсова А.Е. Применение антропологического подхода в современной отечественной педагогической теории и инновационной образовательной практике. Современные проблемы науки и образования, 2014. № 6. URL: https://scienceeducation.ru/ru/article/view?id=15307.

16. Зацерковний В. І., Тішаєв І.В., Демидов В.К. Методологія наукових досліджень : навч. посіб. Ніжин : НДУ ім. М. Гоголя, $2017.236 \mathrm{c.}$ URL: http://dspace.ksau.kherson.ua/bitstream/handle/123456789/4642/МЕТОДОЛОГІЯ\%20НАУ KOВИХ.pdf? sequence $=1 \&$ isAllowed $=\mathrm{y}$.

\section{References:}

1. Khrykov Ye.M. (2018). Metodolohiia pedahohichnoho doslidzhennia: monohrafiia [Methodology of pedagogical research: monograph]: Monohrafiia. Kharkiv, 294. Retrieved from: http://dspace.luguniv.edu.ua/jspui/bitstream/ 123456789/4827/1.pdf. [in Ukrainian].

2. Kustovska O. V. (2005). Metodolohiia systemnoho pidkhodu ta naukovykh doslidzhen: Kurs lektsii [Methodology of systems approach and research: Course of lectures]. Ternopil : Ekonomichna dumka, 124. Retrieved from: http://library.wunu. edu.ua/files/EVD/kl_mspnd.pdf. [in Ukrainian].

3. Kornetov H.B. (1995). Tsyvylyzatsyonnyi podkhod kak metod ystoryko-pedahohycheskoho yssledovanyia aksyolohycheskykh problem obrazovanyia [Civilizational approach as a method of historical and pedagogical research of axiological problems of education]. Obrazovanye: ydeal y y tsennosty (ystoryko-teoretycheskyi aspekt). Moskva, 16-34 [in Russian].

4. Dubaseniuk O.A., Antonova O.Ie. (2017). Metodyka vykladannia pedahohiky [Methods of teaching pedagogy]: kurs lektsii: vyd.2, dopovnene. Zhytomyr: Vyd-vo ZhDU im. I. Franka, 327. Retrieved from: http://eprints.zu.edu.ua/29033/1/kurs\%20lektsii.pdf [in Ukrainian].

5. Nikolaiesku I.O. (2016). Naukovo-metodychnyi suprovid profesiino-pedahohichnoi samorealizatsii vykladacha systemy pisliadyplomnoi osvity zasobamy informatsiinokomunikatsiinykh tekhnolohii [Scientific and methodological support of professional and pedagogical self-realization of a teacher of postgraduate education by means of information and communication technologies]. Narodna osvita, 3, 35-41. Retrieved from: http://nbuv.gov.ua/UJRN/NarOsv_2016_3_8. [in Ukrainian].

6. Stoliarenko L.D. (2003). Pedahohycheskaia psykholohyia [Pedagogical psychology]. Seryia «Uchebnyky y uchebnye posobyia». 2-e yzd., pererab, y dop. Rostov n/D: «Fenyks», 544 [in Russian].

7. Mashkina S.V., Usatenko T.P., Khomych L.O., Shakhrai T.O. (2016). Teoretychni zasady kulturolohichnoho pidkhodu u pidhotovtsi pedahoha do vykhovnoi diialnosti [Theoretical bases of culturological approach in preparation of the teacher for educational activity]. Monohrafiia. IPOOD NAPN Ukrainy, 168. Retrieved from: https://core.ac.uk/download/pdf/141487946.pdf. [in Ukrainian].

8. Hessen S.Y. (1995). Osnovy pedahohyky. Vvedenye v prykladnuiu fylosofyiu [Fundamentals of pedagogy. Introduction to applied philosophy]. Otv. red. y sost. P.V. Alekseev. Moskva: «Shkola-Press», 448. Retrieved from: https://dbs-lin.ruhr-uni-bochum.de/personalitaet/pdf/111.pdf. [in Russian].

9. Vitvytska S.S. (2006). Osnovy pedahohiky vyshchoi shkoly [Basics of higher school pedagogy] : pidruch. za modul.-reitynh. systemoiu navchannia dlia studentiv mahistratury. M-vo osvity i nauky Ukrainy, Zhytomyr. derzh. un-t imeni Ivana Franka. Kyiv: Tsentr navch. lit., 383 c. : rys, skhemy. [in Ukrainian].

10. Kornetov H.B. (2003). Ystoryia pedahohyky [History of pedagogy] : Vved. v kurs «Ystoryia obrazovanyia y ped. Mysly» : Ucheb. posobye dlia studentov vuzov, obuchaiushchykhsia po spetsyalnostiam (OPD.F. 02. - Pedahohyka). Moskva : Yzd-vo URAO, 292, [2]. (Pedahohycheskoe znanye / Un-t Ros. akad. obrazovanyia) [in Russian].

11. Lynenko A.F. (2016). Profesiina identychnist $v$ konteksti profesiinoi pidhotovky maibutnoho vchytelia: teoretychnyi aspekt doslidzhennia [Professional identity in the context of 
professional training of future teachers: the theoretical aspect of the study]. Nauka i osvita, 1, 72-76. Retrieved from: http://nbuv.gov.ua/UJRN/NiO_2016_1_16. [in Ukrainian].

12. Sukhomlynska O.V. (2007). Metodolohiia doslidzhennia istoryko-pedahohichnykh realii druhoi polovyny XX stolittia [Methodology of research of historical and pedagogical realities of the second half of the $X X$ century]. Shliakh osvity, 4, 6-12. Retrieved from: https://lib.iitta.gov.ua/9006/1/Stattia\%20O.V.\%20Sukhomlynskoi1.pdf. [in Ukrainian].

13. Kurliand Z.N., Khmeliuk R.I., Semenova A.V. ta in. (2007). Pedahohika vyshchoi shkoly [Pedagogy of High School] : Navch . posib. / Za red. Z.N. Kurliand. 3-tie vyd., pererob. i dop. Kyiv: Znannia, 495. Retrieved from: https://library.udpu.edu.ua/library_files/416808.pdf. [in Ukrainian].

14. Khrykov Ye.M. (2005). Metodolohichna funktsiia zakoniv ta zakonomirnostei pedahohichnoi nauky u istoryko-pedahohichnykh doslidzhenniakh [Methodological function of laws and regularities of pedagogical science in historical and pedagogical researches]. Zbirnyk naukovykh prats. Pedahohichni nauky. Vypusk 40. Kherson: KhDU, 460, 37-42. [in Ukrainian].

15. Fyrsova A.E. (2014). Prymenenye antropolohycheskoho podkhoda $v$ sovremennoi otechestvennoi pedahohycheskoi teoryy y ynnovatsyonnoi obrazovatelnoi praktyke [Application of the anthropological approach in modern domestic pedagogical theories and unnovatsionnoy educational practice]. Sovremennye problemy nauky y obrazovanyia, 6. Retrieved from: https://science-education.ru/ru/article/view?id=15307. [in Russian].

16. Zatserkovnyi V. I., Tishaiev I.V., Demydov V.K. (2017). Metodolohiia naukovykh doslidzhen [Research methodology] : navch. posib. Nizhyn : NDU im. M. Hoholia, 236. Retrieved from: http://dspace.ksau.kherson.ua/bitstream/handle/123456789/4642/METODOLOHIIa\%20 NAUKOVYKh.pdf?sequence=1\&isAllowed=y. [in Ukrainian]. 